Portland State University

PDXScholar

5-7-1993

\title{
The Political Reception of Erich Maria Remarque's Im Westen Nichts Neues in the Late Weimar Republic
}

Richard Jay Cogburn

Portland State University

Follow this and additional works at: https://pdxscholar.library.pdx.edu/open_access_etds

Part of the German Literature Commons

Let us know how access to this document benefits you.

\section{Recommended Citation}

Cogburn, Richard Jay, "The Political Reception of Erich Maria Remarque's Im Westen Nichts Neues in the Late Weimar Republic" (1993). Dissertations and Theses. Paper 4563.

https://doi.org/10.15760/etd.6447

This Thesis is brought to you for free and open access. It has been accepted for inclusion in Dissertations and Theses by an authorized administrator of PDXScholar. Please contact us if we can make this document more accessible: pdxscholar@pdx.edu. 
AN ABSTRACT OF THE THESIS OF Richard Jay Cogburn for the Master of Arts in German presented May 7, 1993.

Title: The Political Reception of Erich Maria Remarque's $\underline{\text { Im Westen }}$ Nichts Neues in the Late Weimar Republic

APPROVED BY THE MEMBERS OF THE THESIS COMMITTEE:

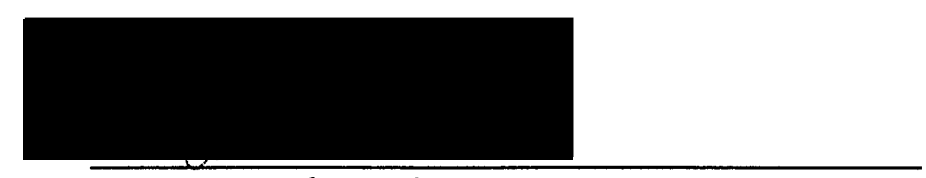

Timm Menke, Chair

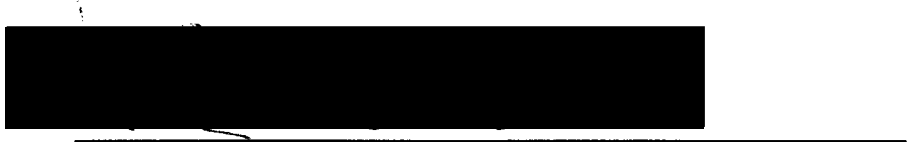

Louis Elteto

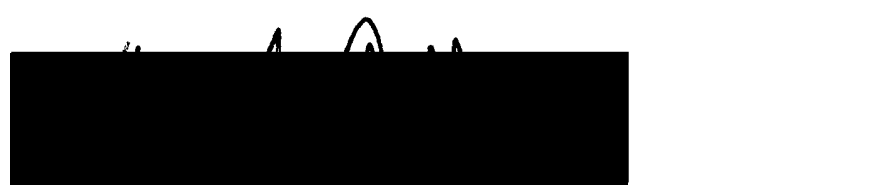

Steven Fuller

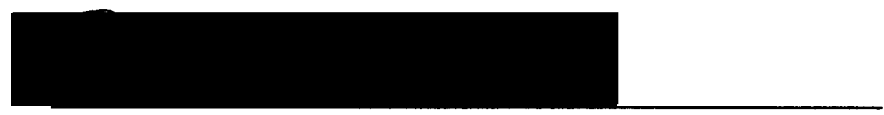

Franklin C. West

The novel Im Westen Nichts Neues first appeared in Germany in January 1929 and became an overnight success. Its author, Erich Maria Remarque, was a shy, quiet man who had not anticipated such 
success. His novel was written to be a fictitious account of the lives of a few students-turned-soldier and their comrades in the front-line trenches of World War I. This was a unique perspective on the war. The earlier books about the war had been mostly the published, factual memoirs of former officers and as such were written from an elitist and nationalist point of view. Remarque's fictional characters, conversely, were young privates doing their duty and suffering through the dehumanizing effects of their military training and life at the front. They lost touch with their past and came to be able to see nothing in their future except war. These soldiers found themselves lost between a past with which they were no longer able to identify and a future in which, because of the terror and daily life-and-death struggle they currently faced, they could not imagine being able to take anything seriously.

Coming out in favor of the novel were the critics aligned with the liberal and left-liberal political arenas. This group of critics proclaimed that the novel portrayed the truth about the war in all of its horror. Having been written from the perspective of the unknown German soldier, it, unlike any other heretofore published work about the war, told the story of the every day, non-elitist soldier and his thoughts. The novel was pacifistic in nature and was therefore in line with the current world opinion, following closely on the heels of the international signing of the Kellogg-Briand Peace Pact.

On the other hand, the Communist left and the entire spectrum of the political right denounced Im Westen Nichts Neues as a lie and 
Remarque as an anti-German author bent on the degradation of the German national honor. The Communists decried the novel as being arbeiterfeindlich because it did not recognize the political- economic causes of the war and because it contained no call for the oppressed to revolt against the upper classes. They therefore deemed Remarque a member of the sterile-minded bourgeoisie.

The rightists, in their denunciation of the novel, took exception to the lack of heroes and glorification of the war in the book.

Kameradschaft was given the credit for heroism. This idea was repugnant to the nationalists, and in fact worked as a threat to their reason for existence. With Remarque further depicting the soldiers as acting instinctively to protect themselves from annihilation rather than fighting with thoughts of the glorious renewal of the fatherland, it was too much. They proclaimed the novel to be a lie which had been written by, among other descriptions of Remarque, a tender, pacifistic little soul who had never seen a battlefield in his life. 
THE POLITICAL RECEPTION OF ERICH MARIA REMARQUE'S

IM WESTEN NICHTS NEUES

IN THE LATE WEIMAR REPUBLIC

\author{
by \\ RICHARD JAY COGBURN
}

A thesis submitted in partial fulfillment of the requirements for the degree of

MASTER OF ARTS

in

GERMAN

Portland State University
1993 
TO THE OFFICE OF GRADUATE STUDIES:

The members of the Committee approve the thesis of Richard Jay Cogburn presented May 7, 1993.

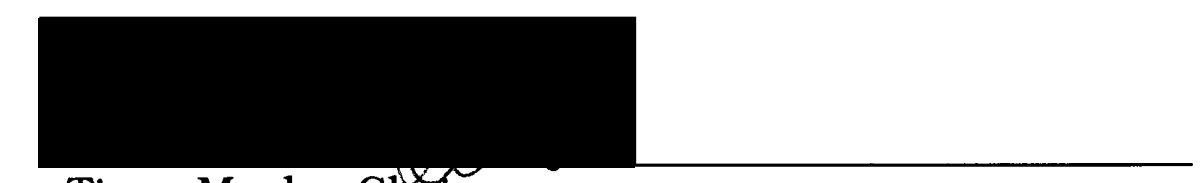

Timm Menke, Chair

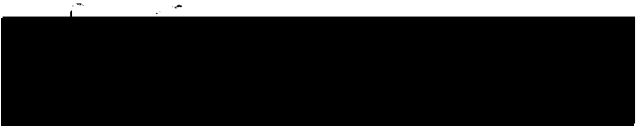

Louis Elteto

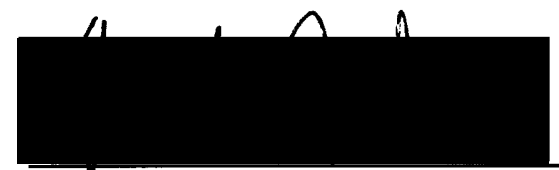

Steven Fuller

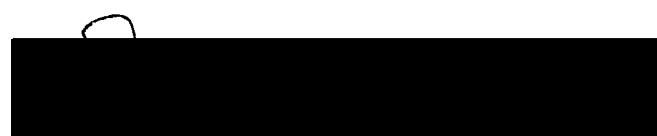

Franklin C. West

APPROYEĐ:

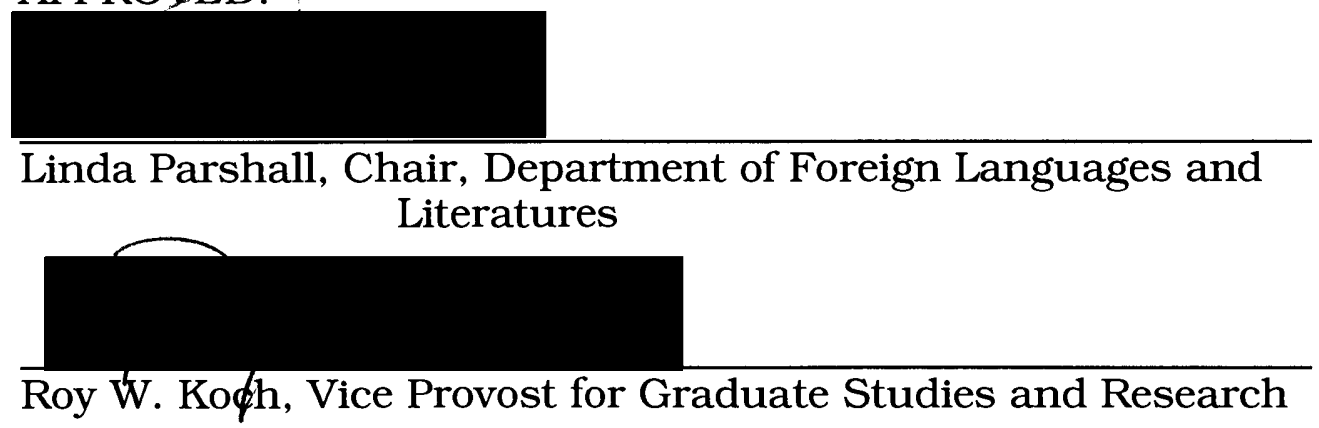




\section{ACKNOWLEDGEMENTS}

I would like to express my appreciation to my thesis advisor, Dr. Timm Menke, for his guidance, support, and for adjusting his schedule to accomodate mine. I would further like to express my gratitude to my wife, Karen, for putting up with all my evenings away doing research and the weekends spent writing while she took care of both of our children alone, and to my children, Katie and Adam, for their patience with me as I worked. Finally, I would like to thank my computer expert, Dan Domenigoni, for his assistance in that technical area of my work. 
TABLE OF CONTENTS

PAGE

ACKNOWLEDGEMENTS . . . . . . . . . . . . . . . iii

CHAPTER

INTRODUCTION $\ldots \ldots \ldots \ldots \ldots \ldots \ldots \ldots \ldots \ldots \ldots \ldots \ldots$

Purpose $\ldots \ldots \ldots \ldots \ldots \ldots \ldots \ldots \ldots$

I THE NOVEL IM WESTEN NICHTS NEUES $\ldots \ldots \ldots \ldots 6$

Introduction $\ldots \ldots \ldots \ldots \ldots \ldots$

The Dehumanizing Effects of Military

Training and the War ..............

Losing Touch with the Past . . . . . . . . 13

The Future $\ldots \ldots \ldots \ldots \ldots \ldots \ldots \ldots$

Kameradschaft ................ 18

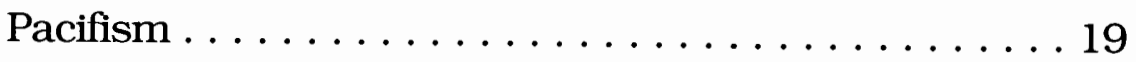

II ERICH MARIA REMARQUE . . . . . . . . . . . 22

Remarque: A Short Biography . . . . . . . . . 22

Remarque's Intentions in Writing the

Novel ...................... 24

III CRITICISM FROM THE LEFT . . . . . . . . . . 27

Communist Reaction $\ldots \ldots \ldots \ldots \ldots 27$

Liberal and Left-Liberal Reaction . . . . . . . . . . . 34 
IV CRITICISM FROM THE RIGHT . . . . . . . . . . . 42

Rightist Denunciation of Im Westen

Nichts Neues . . . . . . . . . . . . . . . . . 42

Rightist Attacks on Remarque . . . . . . . . 47

CONCLUSION $\ldots \ldots \ldots \ldots \ldots \ldots \ldots \ldots \ldots \ldots \ldots \ldots \ldots \ldots \ldots \ldots \ldots$

ENDNOTES . . . . . . . . . . . . . . . . . . . . 62

REFERENCES . . . . . . . . . . . . . . . . . . . 70 


\section{INTRODUCTION}

"Down with literary betrayal of the soldiers of the World War! In the name of educating our people in the spirit of valor, I commit the writings of Erich Maria Remarque to the flames" [1]. With these words, spoken on May 10, 1933 by pro-National Socialist students in what the party claimed were spontaneous gatherings of students at various universities around Germany [2], the novel Im Westen Nichts Neues was banned in Germany by the National Socialist Party after having been in print there for just over four years. The movie based on the book had been banned almost upon its release nearly two and one-half years earlier by the Social Democrat government, bowing to pressure from the National Socialists, on the grounds that its showing was thought to be an unnecessary threat to public order [3].

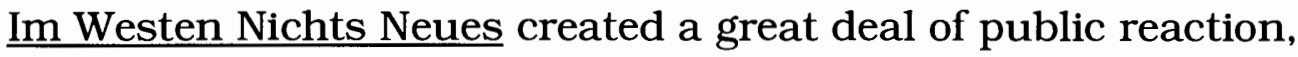
both positive and negative, during its initial four years in Germany. Although it was not the first war novel to appear, it quickly became the most popular one, with its sales reaching one-half million within twelve weeks of its release at the end of January, 1929, and topping one million copies sold at the end of its first year on the market. By this time, it had also been translated into fourteen languages, and was produced in Braille, with these copies being presented to blinded ex-soldiers in May, 1930 [4]. These figures are somewhat amazing considering that the novel 
first appeared ten years after the war and was, according to its author, written without difficulty over a period of six weeks merely as an exercise to free his mind $[4,5]$. That it was a success was both unexpected and depressing to Remarque, who contemplated suicide in the months following its publication [5].

The story of Paul Bäumer and his comrades was written in the style of Neue Sachlichkeit, a style which Kurt Pinthus [6] described as:

. . . unpathetisch, unsentimental, schmucklos, und knapp; ... ohne lyrisches Fett, ohne gedankliche Schwerblütigkeit, hart, zäh, trainiert. . . .

The book glorified neither the soldier nor the war. Rather, it told in often crude, often gruesome detail of the life of a front line soldier and the feelings of loss and confusion suffered by him and his friends. Within

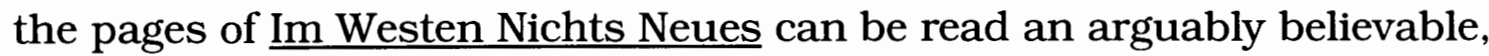
yet obviously fictionalized [7] account of the war from the viewpoint of a common soldier who sees neither the "big picture" nor the anticipated glory of this supposedly great adventure, but rather feels the terror and sees the horrifying deaths and suffering which take place in his part of the war.

Explanations for the success of $\underline{\operatorname{Im} \text { Westen Nichts Neues are }}$ varied. One is certainly that many who read Remarque's novel agreed with what they read, claiming that this was indeed how their war experience had been $[8,9]$. This view is supported by an article in the April 5, 1931 Frankfurter Zeitung, Literaturblatt Nr. 14 by Ephriam Frisch [10], who suggested that the language of the novel spoke to those 
who had experienced the war, either at home or at the front but had been unable to clearly express what had occurred. These people found that they were able to identify with the story and, in a low key way, either celebrate the memories or let what was buried in their feelings out in a gentle way. He further asserted that one of the most important features of Remarque's work is that it takes hold of the reader rather than attacking him.

A second explanation for the success of the novel is the media blitz laid on by Ullstein Press. During this four week campaign "on a scale never before witnessed in German publishing" [11], the German public was prepared for the release of the story, which was first serialized in the Vossische Zeitung, by a series of four simple posters plastered, one each week, onto Berlin's advertising pillars. A result of this campaign was initially only a slight rise in the sales of the newspaper as people became interested in the serialized version of the story. Significantly, however, the attention given the story prompted advance orders of about 10,000 copies of the book at Ullstein Verlag.

Yet another possible reason for the novel's success was brought forth by Carl von Ossietzky in April 1932 in his publication, Die Weltbühne. In his article, von Ossietzky wondered why the political right was so agitated by Remarque's book, claiming that "[d]er Verfasser wäre heute [April 1932] schon ebenso vergessen wie sein Buch, wäre nicht die Rachsucht der Chauvinisten." [12] Although he conceded that such a novel could be a powerful weapon against the right wing if it were 
backed by the right man, he concluded that "Remarque sei kein solcher Mann ..." [12].

Whatever the explanation for its success, $\underline{\text { Im Westen Nichts Neues }}$ was discussed, debated, upheld as realistic war material, and denounced as the whinings of a low class private who was made to leave the comforts of his home to do his duty for his country [13]. It became the banner around which gathered those who believed the war to have been a senseless waste of Germany's younger generation on the one hand, and conversely was seen as an attempt to undermine German pride, honor, and nationalism through its overt exclusion of the feelings of honor a soldier should have in performing his duty, in killing and possibly dying for his country. The novel was finally banned and burned during National Socialist student gatherings shortly after Adolf Hitler came into power in 1933.

\section{PURPOSE}

This thesis will examine the political reception of the novel $\underline{\mathrm{Im}}$ Westen Nichts Neues. In the first chapter, it describes several aspects of the novel in some detail. The second chapter discusses the author, his background, and his intentions in writing the novel. These first two chapters then serve as a background against which the reception of the book by critics associated, either officially or unofficailly, with four political factions of late Weimar Germany will be framed. Subsequent chapters discuss the reception and critique of the novel by critics aligned 
with the National Socialists, the Communists, and the left- and right-center political arenas. 


\section{CHAPTER I}

\section{THE NOVEL IM WESTEN NICHTS NEUES}

\section{INTRODUCTION}

In its preface, the novel $\underline{I m}$ Westen Nichts Neues professes to be a report on a "generation of men who, even though they may have escaped its shells, were destroyed by the war" [14]. This destruction comes about through the life-saving, yet dehumanizing effects of both military training and of fighting in the front trenches. Its effects are intensified through the soldiers' losing touch with their past and through their feeling that there is no future beyond the war. As counterpoint to this dehumanization, throughout the novel runs the more positive theme of Kameradschaft, which serves as a constant anchor point with the help of which the soldiers are able to maintain their sanity. Their comrades become their substitute family as well as, in many cases, their source of strength to overcome the immediate circumstances in which they find themselves.

The overall sense of the novel is one of pacifism. Each of the areas mentioned above lends itself to this feeling as it addresses the undoing of the young men in the story. This is further evidenced throughout the novel by the lack of language which would serve to lend an adventurous tone to the story. Instead, the story is told in terms which though 
simple, convey the tension, the horror and the ugliness of the battlefield. When the soldiers in the story have been relieved and are in the rear areas, the reader learns of their crudeness, and their black humor, but perhaps most significantly, of their hopes and their philosophy, much of which is directed against the older generation which accepted the war on their behalf, and against the idea of war itself.

\section{THE DEHUMANIZING EFFECTS OF MILITARY TRAINING AND THE WAR}

The beginning of the characters' regression from what is commonly considered normal human values takes place during their ten week training period under the brutal Corporal Himmelstoß. Paul Bäumer, the story's main character and narrator, was forced, among other menial duties, to make the corporal's bed fourteen times in one morning, scrub out the Corporals' Mess with a toothbrush, and, along with one of his former schoolmates, Albert Kropp, clear the barrack square of snow with a handbroom and dustpan [15]. The recruits soon began to see that all of their formal schooling was meaningless to the military machine.

Wir lernten, daß ein geputzter Knopf wichtiger ist als vier Bände Schopenhauer. Zuerst erstaunt, dann erbittert und schließlich gleichgültig erkannten wir, daß nicht der Geist ausschlaggebend zu sein schien, sondern die Wichsbürste, nicht der Gedanke, sondern das System, nicht die Freiheit, sondern der Drill [16].

This early learning was reinforced by events in the field. After having been at the front for some time, several members of Bäumer's company discuss and make fun of their earlier learning. Their 
conclusion is that their school learning is "rubbish" since it had never been useful in their experience. In school,

... niemand hat uns in der Schule beigebracht, wie man beim Regen und Sturm eine Zigarette anzündet, wie man ein Feuer aus nassem Holz machen kann -- oder daß man ein Bajonett am besten in den Bauch stößt, weil es da nicht festklemmt wie bei den Rippen [17].

The worth of formal education and learning in general was reduced yet further in Paul's eyes when, while in the hospital after having been wounded, he has the opportunity to see first hand the variety and extent of wounds which can be suffered. Upon consideration of the fact that there would be perhaps hundreds of thousands of such hospitals in Germany, Russia, and France, he notes:

Wie sinnlos ist alles, was je geschrieben, getan, gedacht wurde, wenn so etwas möglich ist! Es muß alles gelogen und belanglos sein, wenn die Kultur von Jahrtausenden nicht einmal verhindern konnte, daß diese Ströme von Blut vergossen wurden. ... [18].

That the soldiers have in fact been dehumanized by the military and that this dehumanization is recognized by the soldiers themselves, is evidenced by a statement made by Bäumer shortly after the arrival at the front of Corporal Himmelstoß. The soldiers' former training officer had gone too far with some of his recruits at the training center and was, as a result, sent to serve in the trenches. Because of their hatred for Himmelstoß, two of Bäumer's comrades, Tjaden and Kropp, insulted him and were therefore brought up before a court-martial. Their company commander's understanding of the source of their hatred lead to light sentences for both men. That soldiers convicted in a 
court-martial used to be tied to trees, muses Paul, is no longer allowed. "Manchmal werden wir schon wie Menschen behandelt" [19].

The dehumanizing effects of the war itself on the individual are manifested most clearly while the soldiers are on the front lines, although they are carried with the soldiers into the rear areas as well. On the front during an attack, the soldiers become animal-like; "Aus uns sind gefährliche Tiere geworden. Wir Kämpfen nicht, wir verteidigen uns vor der Vernichtung" [20]. The fighting then, is not fighting in which rational thought drives those involved. Rather it is a fight in which the drive of animal instinct enhances the soldiers' chances of survival. "Das Grauen läßt sich ertragen, solange man sich einfach duckt -- aber es tötet, wenn man darüber nachdenkt" [21].

Bäumer and his comrades discover that becoming an animal is what saves their lives. They realize later that this life-saving retreat from humanity also has a negative side in that it diminishes them as men over the years [22]. They fear, especially toward the war's end, that they may never be able to return to their pre-war beliefs that life has worth and that there can be a future in which they can play a meaningful, positive role. It is their misfortune, they are powerless to stop the degradation in which they are being steeped. This group to which Bäumer belongs, the group of students who entered the war directly after graduation while the war was in its early stages and remain for the duration are Remarque's "lost generation" [23].

They are lead by their front-line experiences to see life "nur auf 
einer ständigen Lauer gegen die Bedrohung des Todes", a circumstance which causes them to view their lives and the events surrounding them with the "Gleichgültigkeit von Wilden" [24]. This indifference and the acceptance of it helps them maintain their sanity in the face of an attack and what they are forced to do to repel and counter it. It is also this indifference that leads them to accept without question the fact that Müller, one of Paul's former classmates, wants to have the boots of another soldier who, as the result of the amputation of his leg, dies of gangrene. That his boots hurt his feet is reason enough for Müller to stand watch over his dying comrade so he may inherit the boots, an act that in normal society would be deemed macabre and uncaring. It is made clear in the story that the men care about each other. The reality of their situation, however, does not often allow for such emotion, particularly if it hinders the meeting of real needs. In an existence as miserable and mean as theirs, sentimentality is not a luxury which they can afford.

Perhaps the most telling example of the dehumanization of the front soldiers is told in Bäumers description of a counterattack. After three days and nights of bombardment followed by a ground attack, the soldiers should have been too exhausted.

Wären wir keine Automaten . . . wir blieben liegen, erschöpft, willenlos. Aber wir werden wieder mit vorwärts gezogen, willenlos und doch wahnsinnig wild und wütend, wir wollen töten . . .Wir haben alles Gefühl füreinander verloren . . . Wir sind gefühllose Tote, die durch einen Trick, einen gefährlichen Zauber noch laufen und töten können [25]. 
This description of themselves as both machine and dead men who are still somehow capable of killing seems the ultimate description of the dehumanized soldier. To further the image, however, Remarque continues the scene. As the scene of the counterattack unfolds, descriptions of French soldiers being bayonetted, shot, decapitated, and blown apart are given. In the midst of the slaughter, the German soldiers, after reaching the enemy trenches, pilfer whatever food they can find, catering to basic human needs in a situation which would cause humans under normal circumstances to recoil in horror.

Their dehumanization protects the soldiers not only from the enemy on the other side of the battlefield, but protects them from themselves as well. Their desensitized nature allows them to kill without conscience, without thinking of the soldiers they kill as anything other than "the enemy".

The soldiers' degradation was not impermeable, however. At one point, Paul must kill a French soldier who has jumped into the same shell crater for cover. He attacks the man with his knife, mortally wounding him. Because of the heavy fire in his sector, however, Paul is unable to leave the crater until late the following afternoon and is thereby forced to stay near the Frenchman as he dies a slow, painful death. As a result, he must face for the first time the fact that he has killed another human being. To help him maintain his sanity in the face of this trauma, he speaks to his dying victim:

Sprängst du noch einmal hier hinein, ich täte es nicht [ihm 
töten] . . . Aber du warst mir vorher nur ein Gedanke, eine Kombination, die in meinem Gehirn lebte und einen Entschluß hervorrief; -- diese Kombination habe ich erstochen. Jetzt sehe ich erst, daß du ein Mensch bist wie ich. . . . Warum sagt man uns nicht immer wieder, daß ihr ebenso arme Hunde seid wie wir? . . . [26]

This is the second time in the novel that he has come up against the "enemy" and found him to be a man rather than an abstraction, the first time having been as he stood guard over Russian prisoners of war during a short, post-leave training camp assignment. To maintain his ability to do his job and survive, both mentally and physically, in both cases he deliberately embraces the dehumanized side of himself, for "hier darf ich nicht weiterdenken. Dieser Weg geht in den Abgrund" [27]. This vulnerability to their protective shell is a cause for concern, for listed among the casualties from the members of Paul's class is one who is in a mad house as a result of the war. It further speaks to the temporary nature of their protection, which with time must eventually give way.

"Das Grauen der Front versinkt" [28] in the rear areas, but the front is never forgotten and the dehumanized soldier must maintain his guard. Even in the rear areas, the thunder of the guns at the front can be heard and the absence of fallen comrades is felt. The dead are crudely referred to by the soldiers as having "den Arsch zugekniffen" [28] as a mechanism to guard against the insanity of the situation. By looking at their and their comrades' lives in this way, the soldiers are able to maintain a wall between themselves and the madhouse.

Viewed by the press, this black humor is seen as an indication 
that morale is high. Bäumer, however, disputes newspaper articles reporting the good morale at the front based on the fact that the troops who return from the front display a sense of humor and often arrange dances almost immediately upon their return. The truth of the matter, according to Bäumer, is that "we are in a good humour because otherwise we should go to pieces. Even so we cannot hold out much longer; our humour becomes more bitter every month" [29].

\section{LOSING TOUCH WITH THE PAST}

A letter, written to one of the students by their former teacher, Kantorek, a man by now despised as a member of the caste which was responsible for putting them on the front, reveals his belief in them as Germany's "Iron Youth" [30]. The young soldiers, none of whom is older than twenty years, find a bitter irony in this, for they see their youth as being far behind them. The idea of having studied poetry or writing plays seems incomprehensible to them, although "wir haben ja fast alle so etwas ähnliches gemacht" [31].

On a day when Paul is particularly tired following intense fighting, his thoughts turn to memories of home, memories "die mich in meiner Schwäche jetzt heimsuchen und mich sonderbar stimmen" [32]. The memories are idyllic; scenes which are quiet and calm and therefore in direct conflict with the present where the front is always loud with the sound of shelling and the activity level often hectic. It is clear that these memories are romanticized versions of reality which seek to undermine 
his sanity and against which he must struggle.

When sent home on leave, Paul realizes the extent of his alienation from his past. He finds a strange emptiness in his homecoming:

Ich atme langsam ein und aus und sage mir: Du bist zu Hause, du bist zu Hause. Aber eine Befangenheit will nicht von mir weichen, ich kann mich noch nicht in alles hineinfinden. Da ist meine Mutter, da ist meine Schwester, da mein Schmetterlingskasten und da das Mahagoniklavier -- aber ich bin noch nicht ganz da [33].

Sitting at home, surrounded by the evidence of his past, Paul cannot feel at home. Throughout his two week stay at home, he finds one thing after another with which he can no longer identify or be comfortable. His civilian clothing feels too tight, he finds can no longer knot his necktie, and his room with its rows of books and other treasures of his past also seems strange: "Ein fürchterliches Gefühl der Fremde steigt plötzlich in mir hoch. Ich kann nicht zurückfinden, ich bin ausgeschlossen" [34]. In fact, it is not until he is back among his comrades at the front that he feels as though he is once again back where he belongs.

One of the reasons for this distance from the past is certainly the fact that the war had afforded these soldiers a different perspective from which to view life. They have learned to appreciate and depend upon the small things in life, the things necessary to survival, and as a result have come to disdain anything which they see as being frivolous. They argue about and discuss what is real to them under the circumstances. 
Such arguements center around, for example, whether it is better to have a full stomach going into battle for the strength it gives or whether it is better to have an empty stomach in case the outcome of the battle is, for the individual, an abdominal wound [35]. This they count as being more important than any earlier education could ever have been. To them, this means that their formal education and all those who had been involved in subjecting them to such nonsense, as they see it, was to be looked down upon as having been a waste of their time. They now realize that time is a commodity which has the utmost value. This reasoning is purely circumstantial, having been directly brought about by the war with its constant threat to life.

A second and deliberate reason for their having distanced themselves from the past is the fact that they blame the people who were in authority over them throughout their youth for their current predicament. Their parents, teachers, and all others of that generation had welcomed the war with open arms. The soldiers saw this as having been easy to do, especially with the knowledge that they would not be the ones to fight the war, and were understandably bitter about the occurrence. They had been raised for a different life than this and had been thrust unprepared and without choice into the chasm of the war [36]. Now they were expected to happily accept their lot in life and go about the business of murder in the name of and for the sake of their country.

An irgendeinem Tisch wird ein Schriftstück von einigen 
Leuten unterzeichnet, die keiner von uns kennt; und jahrelang ist unser höchstes Ziel das, worauf sonst die Verachtung der Welt und ihre höchste Strafe ruht [37].

\section{THE FUTURE}

Perhaps most devastating of all for Remarque's "lost generation" was the fact that the students-turned-soldiers portrayed in the novel had no hope for their future. When discussing the idea of peacetime, all they can think to do would be to get drunk and make love to buxom women. In a later discussion about the uselessness of their schooling, the talk turns to the kinds of occupations these soldiers might turn to at the war's end. They can imagine nothing that they will be capable of doing, either because their training has not been adequate or because their war experiences would keep them from holding down a job. After all, given the experience of the front lines, who could ever again submit to the demands of an overseer or take the job seriously?

Wir sind eigentlich alle ratlos. "Was könnte man denn machen?" frage ich [Bäumer]. . . .

"Ich habe zu nichts Lust", antwortete Kropp müde. "Eines Tages bist du doch tot, was hast du da schon? Ich glaube nicht, daß wir überhaupt zurückkommen."

Kropp denkt ebenfalls darüber nach. "Es wird überhaupt schwer werden mit uns allen. . . . Zwei Jahre Schießen und Handgranaten -- das kann man doch nicht ausziehen wie einen Strumpf, nachher -- "

"Der Krieg hat uns für alles verdorben" [38].

Thoughts of the future are few and far between because they cause confusion and an emptiness in the soldiers. As the war wears on and 
their situation deteriorates, they lose any hope for an end to it all. Even those who are wounded and who earlier would have been sent home as a result of their wounds are sent back to the front after they have recovered. The only possibilities the soldiers see are "Graben, Lazarett, Massengrab" [39].

When, near the end of the war, it becomes obvious that the war is being lost and there are rumors that an armistice is coming soon, Paul considers the possibility of finally being able to go home. He feels a kind of hope for the future; "[e]s ist Lebensgier, es ist Heimatgefühl, es ist das Blut, es ist der Rausch der Rettung" [40], but finds that he can think no further than just that. The war, had it ended earlier, might have allowed him to find a purpose to his life beyond his experience with death. But because the war dragged on for as long as it did, he believes that the returning "old hand" soldiers will not be able to adapt again to civilian life.

Wenn wir jetzt zurückkehren, sind wir müde, zerfallen, ausgebrannt, wurzellos und ohne Hoffnung. Wir werden uns nicht mehr zurechtfinden können.. . . die Jahre werden zerrinnen, und schließlich werden wir zugrunde gehen [41].

He concludes with the statement that whatever the years may bring, they can take nothing from him because he has nothing left; the coming months and years hold no terror for him. Whether or not he honestly believes this is left to the reader to decide, but in the final sentence of the novel it appears that his death is a relief: "[S]ein Gesicht hatte einen so gefaßten Ausdruck, als wäre er beinahe zufrieden 
damit, daß es so gekommen war" [42].

\section{KAMERADSCHAFT}

The theme of Kameradschaft recurs throughout the novel as the soldiers come to rely on each other for their survival. Their relationship is one which far exceeds the relationship that develops between workers in any other occupation. Kameradschaft, which functions as a form of protection similar to the dehumanization of the soldiers on the front [43], is understood by Bäumer to be "ein festes, praktisches Zusammengehörigkeitsgefühl" [44] between soldiers. He sees this bond as the finest thing to arise from the war.

The bond of Kameradschaft is strongly evidenced between

Stanislaus Katczinsky, known throughout the novel as Kat, and Paul. On the evening following the court-martial of Tjaden and Kropp, Paul and Kat go off, steal a goose, butcher and roast it in a lean-to they have made for such purposes. While the goose is cooking, Paul notes that he and Kat say little to each other, yet "wir sind voll zarterer Rücksicht miteinander, als ich mir denke, daß Liebende es sein können" [45]. When the bird is done, the two encourage each other to take the best parts, showing a caring which contrasts starkly with the savagery of the front. This caring is the essence of Kameradschaft, yet without the war there would be no grounds for its existence [46]. Paul realizes that they really know nothing of each other and that before their common experiences at the front, they would have had nothing at all in common. 
Still, here they are, on such intimate terms with each other that they need not speak [47].

Kameradschaft is not limited to these two, obviously, but rather permeates the front. The bond grows between the soldiers and transcends all boundaries that society would normally have placed between them. It is a social leveler which almost completely eradicates class "Unterschiede, die Bildung und Erziehung schufen" [48]. The soldiers at the front see themselves as entities with the common bond of the front experience. In their Kameradschaft, individuality is suspended and becomes embarrassing. It is a group dynamic which protects the individual from the horror of solitude, of having to face the war on his own. It is the great forgiver, as can be seen by the fact that even the hated Himmelstoß is eventually accepted by those whom he tormented throughout their initial training days. Like the dehumanization which they experience and cling to, Kameradschaft is a vital part of the soldiers' survival mechanism.

\section{PACIFISM}

That the novel $\underline{I m}$ Westen Nichts Neues is pacifistic in nature is undeniable. This is evidenced in part by the matter-of-fact reporting of the fighting, the killing, and the dying. There is no attempt made in the story to create the feeling that there is an element of glory or adventure in the work which has been assigned the soldiers. In fact, in A. W. Wheen's English translation of the novel's preface, the statement is 
made that the story is to be considered "least of all an adventure, for death is not an adventure to those who stand face to face with it" [49]. Throughout the story line are outcries against the senselessness of the war and the death and suffering it brings.

As Paul is lying in the shell crater with the Frenchman he killed, he is overcome with remorse. In his ensuing panic, he decides that he will write to his victim's family to let them know how he died, but later, when his panic subsides, rejects the idea. He realizes that he would never write to the man's wife, that he could never do so and maintain his invulnerability to the dreadful requirements his country has placed upon him. His parting statement to his dead victim is the most overt pacifistic statement in the novel.

Kamerad . . . Heute du, morgen ich. Aber wenn ich davonkomme, Kamerad, will ich kämpfen gegen dieses, das uns beide zerschlug: dir das Leben -- und mir -- ? Auch das Leben. Ich verspreche es dir, Kamerad. Es darf nie wieder geschehen [50].

The novel describes in often gruesome detail the horror and pain, both mental and physical, which the soldiers must endure. The war is portrayed as a "demeaning and wholly destructive force" [51], and indeed as a force over which the soldiers have no influence or control. They stand helpless in the face of it, trusting to their luck, but knowing all the time that "[n]o soldier outlives a thousand chances" [52]. This indication of hopelessness and helplessness flies in the face of those who extol war and dying for one's country as virtuous and heroic and cries out against any who would accept such horrific events ever again. 
This, along with the dehumanization of the soldiers and the loss of their past and future, combine to create a powerful indictment of the war and its consequences, and therein lies the novel's claim to the title of "pacifistic literature". 


\section{CHAPTER II}

\section{ERICH MARIA REMARQUE}

As a further preface to the political critique of $\underline{I m}$ Westen Nichts $\underline{\text { Neues, }}$, it is necessary to understand something of the author, his personal experiences in the war, and about his intentions in writing the novel. All of this information about Remarque, as well as a great amount of misinformation, was made public. The intentions of those digging into Remarque's past were either to lend validity to or discredit the novel, depending upon the individual critic's point of view.

\section{REMARQUE: A SHORT BIOGRAPHY}

Born in 1898, the son of a Catholic book binder, Erich Paul Remark was raised in Osnabrück "in kleinbürgerlicher Atmosphäre" [53]. He finished his schooling in 1916 and was sent, apparently as a member of the 91st Infantry Regiment [54], to serve on the Western Front. While there, he was, according to an interview with Axel Eggebrecht, "mehrfach verwundet" [53]. There is actually a great deal of controversy surrounding Remarque's military service. Whether heenlisted or was conscripted and how often he was wounded, as well as the extent and origin of the wounds is questionable. According to Eksteins [55], Remarque saw front line fighting in Flanders in 1917, was wounded, 
and spent the time from August 1917 through October 1918 in a hospital in Duisburg. In 1930, an author who claimed to have been one of Remarque's acquaintances in the Duisburg hospital wrote that Remarque's wound had been the product of a "Heimatschuß" and that after his recovery Remarque stayed on as an orderly in the hospital [55, $56]$.

After the war, Remarque, who found life in peace time as confusing as it had been during the war, held down a variety of jobs. These included those of writer of advertising copy for a tire company and as a sportswriter for the high society magazine "Sport im Bild" in Berlin [57]. During this time, he assumed the pen name Erich Maria Remarque and wrote, among other literature, Im Westen Nichts Neues. With the novel's astonishing success, a great industry sprang up which on the one hand praised the novel as being the great war book of the time and on the other hand denounced the novel on a wide variety of bases as being rubbish. Remarque, being a relatively shy man, chose to stay out of the limelight:

[w]eil ich es nicht für notwendig hielt und halte. . . . [W]enn eine Arbeit fertig ist, hat der Autor zu ihr nichts mehr zu bemerken, selbst auf die Gefahr hin, daß er mißverstanden wird. . . . Ich bin aber die Meinung, da $\beta$ ich nur dort mißverstanden worden bin, wo man von vornherein mißverstehen wollte [58].

Prior to Hitler's coming to power in 1933, Remarque relocated to Ascona, Switzerland and later to New York, where he eventually became a citizen of the United States. Between these two cities he lived out the 
remainder of his life. Before he died in 1970, Remarque wrote several other novels. All of these met with some success, but none found the same level he met with $\underline{\text { Im Westen Nichts Neues. }}$

\section{REMARQUE'S INTENTIONS IN WRITING THE NOVEL}

When Remarque sat down in early to mid-1928 to write Im Westen Nichts Neues, it was not his purpose to write an objective, general description of the war. The book was not to be an autobiographical account, but rather a story about the experiences of a student-turned-soldier and his friends during the last two years of the war. It was to be a story of these experiences "nur aus der Froschperspektive des einfachen Grabensoldaten" [59]. In fact, Remarque never intended the book to become a Kriegsbuch [60]. Instead, it was a purposeful attempt to portray a generation of young men for whom the war had been the strongest shaping influence on their perception of life [61]. Further, it may have been an attempt to explain away the "emotional imbalance" [62] which had been evidenced by his generation's restlessness throughout the Weimar Era.

Remarque strove to keep the novel apolitical. To this end, he, as did many pacifist writers of the Neue Sachlichkeit style [63], went to pains to ensure that his characters did not subscribe to any particular political agenda. Further, he deliberately chose to depict only short outtakes from the life of his protagonist, Paul Bäumer, and excluded dates and places from the story line of the novel [64]. In part, his purpose was to 
not sidetrack the reader with historical detail that could distract him or her from the story's main theme of the "lost generation". It was his expressed purpose to shed light on this generation which had been so unalterably changed by the war that they were unable to get along in post-war society [65].

A second reason for the exclusion of dates and places was that such detail would give the novel the appearance of an autobiographical or historical work. This, he felt, would incorrectly place his novel among the ranks of the war memoirs which had since 1927 become commonplace. His purpose in writing the novel had been to free his mind of the oppression of the war and to write a fictitious account as an explanation of his generation's plight as a result of the war. Dates and places of the events he depicted could only cause confusion about his intentions. It is ironic that such omissions would serve as a focal point of many for his critics who wanted the book to be non-fiction or who interpreted it as such.

Despite allegations to the contrary, Remarque claimed to have written the book based upon his experiences in the war. The story of Paul Bäumer recounts a number of incidents with which some critics took issue. As a case in point, the medical profession took issue with some of the descriptions of extraordinary circumstances on the battlefield: descriptions of men running with both feet shot off, holding an open artery with their teeth to keep from bleeding to death, or of bodies continuing forward motion after their heads had been blown off, 
drew fire. When questioned by Eggebrecht about the realism of his depiction, he replied "'die Situationen', die in seinem [Remarque's] Buch geschildert seien, seien 'wahr und erlebt"' [66].

In Remarque's view, then, his novel was written as an honest portrayal of scenes which he, himself, experienced while serving on the front. This portrayal he fictionalized by writing about fictional people [66] and putting them in settings for which neither time nor place was specified. In so doing, his intention was not to describe the war, but to focus on the far-reaching results of the war's constant threat to life, and to suggest cause and effect for his generation's apparent transient nature. The results of his efforts brought forth a great deal of criticism, both positive and negative, from all sides of the political arena as well as from the public at large. 


\section{CHAPTER III}

\section{CRITICISM FROM THE LEFT}

This chapter discusses the criticism of Remarque's $\underline{\text { Im Westen }}$ Nichts Neues from the point of view of the Communist and left-liberal parties. There was a high degree of division of opinion between the Communist Party and the other, less radical leftist parties. In addition, there was also some division within the Communist Party itself, in which each side of the division tacitly negated the other.

\section{COMMUNIST REACTION}

In a unique critical article published in the March 30, 1929 issue of the Communist Internationale Presse- Korrespondenz by an anonymous writer under the pseudonym of "Mersus", Im Westen Nichts Neues received a positive response. The novel was described as "'zweifellos das stärkste und erschütterndste Werk' aus 'der Flut'" [67] of war books which had been published in the years since the war. The author concluded with, for the Communists, the rather amazing statement that to expect Remarque to call for the workers to rise up against the existing political structure would be wrong. "Mersus" believed that Remarque's worth was that he brought the helplessness 
and denial of the lower class's dead end life to light, causing them to be interested in improving their situation.

That the novel could be advantageous to the cause of Communism was not, however, the official party position. In the party's magazine Internationale Literatur and in its newspapers $\underline{\text { Rote Fahne and Die }}$ Linkskurve, the initial judgment of the KPD regarding $\underline{\operatorname{Im} \text { Westen Nichts }}$ Neues was made clear. Their views were stated without regard to the background of either the novel or the author. Without mention of either the purpose or the reality of Remarque's portrayal of the "lost generation" and the war, the German Communist Party condemned the novel as "arbeiterfeindlich" [68]. It made no difference to the party officials that the book was popular and had been positively accepted by most of the blue collar workers who claimed, if not Marxist allegiance, at least left-liberal alignment. The fact remained that Remarque failed in decrying the political-economic class structure which, according to the Communists, had been the cause of the war. He fell short of an overt call to arms. As a result, Im Westen Nichts Neues was deemed a failure. The critic, Michael Gollbach, understood the Communist Party's stand to mean:

... so muß die totale Diffamierung dieses Buches als massiver Versuch der marxistischen Kritik beurteilt werden, ihrem Lesepublikum vom Kauf und der Lektüre des Buches abzuraten, die Rezeption zu beeinflussen oder nachträglich zu korrigieren [68].

To meet their goal, the Communist press attacked both Remarque and his novel in a variety of ways, many of which had nothing to do with 
political-economic social structure. Their job, as the KPD critics saw it, was to destroy the book by disillusioning its reading public about either Remarque, the concepts which they read in [and read into] the novel, or both.

Their attacks on Remarque himself were less frequent than were their attacks on their perception of the book. They were, however, sharp and to the point. Remarque was denounced as a "Kleinbürger" [69] who, because he was unable to determine the source of Germany's social disorder had, in the true tradition of the sterile bourgeois intelligence, resorted to the use of tearful sentiment in his novel [70]. Remarque was derided as being terrified yet unwilling to awaken any type of active protest and fight. This fear, along with the accusation that Remarque would rather cripple the resistance to the bourgeoisie than to call for social action or revolt, M. Helfand termed "Remarquismus, . . . das Toxin des passiven Gehorsams" [71].

It was not, then, Remarque's values or his background which came under fire from the Communist camp. Instead, it was his perceived passivity. The Communist press was angered because he did not loudly protest the circumstances of the lower class; in other words, he did not mold his story in accordance with their party philosophy. Opportunities for such protest were, in their opinion, presented in the novel, but were not followed up with any call for reform, thereby completely ignoring what the Communists saw as being necessary to their cause.

The Communist attacks on the novel itself were a mixed bag which 
focused on a variety of concepts, some intended by Remarque, others not. To most readers, the book was oriented against the war and was therefore widely accepted as being pacifistic in nature. According to Klaus Neukranz, a writer for Rote Fahne, the novel is "pazifistisch, d.h. unwahr", and went on to denounce pacifism as the most terrible of war lies because it does nothing less than to deny the political-economic causes of the war [72]. The problem was that it laid no blame at the feet of the capitalist social order which the Communists believed had caused the war in the first place. Instead, it placed that blame on the fathers, teachers, and others who had been responsible for the proper upbringing of those who fought the war [73].

Yet another of Remarque's shortcomings, according to the Communist way of thinking, was that he, failed to recognize that the reigning political-economic order was to blame for the war. Logically, then, Remarque must be based in the belief that the war was a result of fate [74]. As such, it could not be seen as the contrived circumstance which they saw it to be. This view could not be tolerated. If it were true that the circumstances of humans lay in the hands of fate, the lower class would have nothing to rise up against. They would have to be forever blown about, helpless and hopeless, by the winds of fate. They would have to believe that their circumstances, their position in life was predetermined. Such an outlook on life could negate the Communist Party's reason for existence.

In accordance with this viewpoint, the Communists took further 
exception to Remarque's treatment of the soldiers in his book, whom they saw as a group which took everything lying down without so much as a thought to revolting or resisting the war [75]. When the soldiers discussed the war, their talk tended to be nebulous, displaying a lack of understanding of the strategy involved in the war as a whole. They apparently understood only what was going on in their immediate vicinity and cared to understand nothing more. This portrayal of the common soldier was unsettling to the Communists, who wanted the soldiers to stand on their own, under the party banner, of course, and fight against the upper classes. Their ability to arise, however, was impeded by the Kameradschaft which Remarque portrayed as having caused a social leveling among those serving at the front. This was seen as a deliberate erasure of factual class opposites [75] and as such, again brought the reason for the party's existence into question.

The response of some Communists, in particular Erich Weinert, to the concept of Kameradschaft took an interesting turn. Remarque, through the character of Paul Bäumer, took the stand that Kameradschaft was the only good thing brought about by the war. Weinert acknowledged that the bond of Kameradschaft was strong and further acknowledged the uncomfortable feelings of those who had lost touch with their pre-war lives and "sich auf dem Schauplatz des Entsetzens wohler fühlten als in ihrer heimatliche Gesichterheit" [76]. This was the basis of his claim that $\underline{I m}$ Westen Nichts Neues recalled the bloodlust and the need for a rekindled Kameradschaft to those who had 
fought in the trenches rather than causing them to be repulsed by the idea of war [76]. There was, then, according to Weinert, no pacifism involved in the novel at all. It was instead a glorification of heroism and the war-induced social leveling which tacitly resulted in what was tantamount to a recall to arms. Under this interpretation, $\underline{\operatorname{Im} \text { Westen }}$ Nichts Neues was not viewed as a pacifistic, anti-war book, but as a cover-up in the preparation for another imperialist war [77]. Further, it caused Remarque to be classified by Weinert and those who subscribed to his interpretation as an "Aufrüstungsdichter". The party's claim to validity in this rather absurd judgment was that "[w]er so den Stoff des Krieges gestalten will, bereitet -- bewußt oder unbewußt -- den nächsten Krieg mit vor" [78].

As important to the Communist Party as the message Remarque had explicitly written in his novel was that which, by his silence, he implied. In the words of K. Kersten: "Das Schweigen in seinem Buch hat auf mich viel tiefer gewirkt als die Schilderung der Schlachterei selbst" [79]. As has already been stated on a number of occasions, and as the main theme of the Communist renunciation of Remarque's novel, the book contained no overt call to action. A. F. Bance, in a more recent critique of the novel, suggests as an explanation for this "failure" on Remarque's part that the novel reflects Weimar Era pacifism, a pacifism which has simple emotional appeal and which:

commits no one to action or sacrifice of his personal interests . . . The very modesty of Remarque's pacifism, such as it is, is highly appropriate to the nature of Weimar society 
... [which had] in the main few ambitions in the direction of radical reform and sought security rather than political revolution [80].

The Communists were, however, strongly interested in political revolution and were not happy that Remarque was not.

They further complained that the political-economic truth about the war and its causes had been fully ignored by the author, as had any reference to opposition and class struggle. These omissions served as the basis for all Communist denunciation of the novel. Remarque's silence with regard to these key points was regarded by the Communists as unreasonable.

Sie [seine Stummheit] ist der Erkenntnis feindlich. Sie steigert den Krieg zum mystischen Schicksal empor, das er nicht ist, und beläßt ihm die Unabwendbarkeit, die er nicht hat $[81]$.

Although the Communist Party agreed, with the exception of the article by "Mersus", that the novel was misdirected, they were unable to come to a clear, unified agreement about what exactly was wrong with

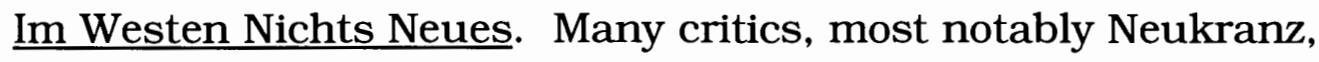
denounced the book as pacifistic and therefore a lie which fully denied the real causes of the war. Weinert and his followers, on the other hand, denied the pacifism of the novel completely, thereby negating the view of Neukranz and his followers. He concentrated instead upon the argument that the book was, as a result of the reawakened yearning among the former soldiers for the glory days in the trenches with their comrades, actually a cover up for a call to rearmament. This view was 
both supported and extended by yet another Communist critic, Karl August Wittfogel, in the July 26, 1930 edition of the Rote Fahne. In his critique, Wittfogel relegated $\underline{I m}$ Westen Nichts Neues to the category of "Aufrüstungsliteratur", a category which had been heretofore reserved for the exclusive denunciation of "repräsentativen [Kriegsbücher] des jungen deutschen Faschismus" such as Ernst Jünger's In Stahlgewittern [82].

\section{LIBERAL AND LEFT-LIBERAL REACTION}

In sharp contrast to the anti-Remarque stance of the Communist Party, the liberal and left-liberal press of late Weimar Germany came down heavily in favor of Remarque's portrayal of his "lost generation". This group of left-wing intelligentsia counted among its numbers several well-known, highly respected authors, and as a result, wielded a great deal of influence among their readers. These authors included Axel Eggebrecht, Ernst Toller, and the most decorated lieutenant of the "Great War", Carl Zuckmayer [83]. In their reviews, which appeared in a variety of liberal and left-liberal newspapers and magazines, the critics documented, and at the same time probably caused a great amount of, the novel's success [84].

The enthusiasm with which these critics met the book at times seems almost an overreaction. To be sure, not all of the critics of this group were favorably inclined toward all aspects of $\underline{\operatorname{Im} \text { Westen Nichts }}$ Neues, but generally speaking, they wrote the majority of favorable critical articles about the novel. 
There were three major themes which drove the engines of the liberal and left-liberal press with regard to Remarque's novel. The first of these was the determination by these critics that the novel told the truth about the war. In fact, in his first review of Im Westen Nichts Neues for the Berliner Illustrierte Zeitung, Carl Zuckmayer proclaimed the novel to be a war diary [85]. Remarque's depiction of the front experience with its crudeness and shockingly gruesome descriptions of battle was praised by the political left as being highly realistic. A common phrase used by both German and non-German critics in describing the novel was that it was the "greatest of all war books", and it was hailed in the London Sunday Chronicle as "the true story of the world's greatest nightmare" [85]. Its realism was reflected in the critique of Oskar Maurus Fontana, who found that the novel touched him in such a way that it often brought tears to his eyes. Moreover, he felt compelled on several occasions to stop reading and run around his apartment "um nicht von seiner [the book's] Verzweiflung, seinem Jammer erdrückt zu werden" [86].

From the SPD came the critique of Anna Siemsen, the party's Kulturfunktionärin, who proclaimed Remarque's novel to be a true and vivid picture of the war as the author saw it. She therefore determined the novel to be "absolut unrevolutionär" [87]. Further, she believed that Im Westen Nichts Neues would belong to those documents which would show the world how and why the German people lived through the war as they did, long after its popularity as a novel had subsided. 
The peace movement's press also joined in with praise for $\underline{\operatorname{Im}}$ Westen Nichts Neues, suggesting that it not only accurately described the war in terms the former soldiers would understand, but explained itself clearly enough for those who had not been at the front to understand as well. Walter Karsch's critique, which was published in Friedenswarte stated that:

Das Buch zeichnet den Krieg, wie er gewesen war. Wahrheitsgetreu, überzeugend und erschütternd, bildet Remarque das scheußliche Verbrechen ab. Den Frontkämpfern schenkte er das Erinnerungsbuch; denen, die nicht dabei waren, zeigte er das wirkliche Gesicht des Krieges [88].

The second theme of the liberal and left-liberal critical press was that the critics of this political persuasion saw the novel as belonging to the people. Much of their critique was therefore directed toward the assertion that the identity of the story's characters was essentially the identity of the common German. Im Westen Nichts Neues broke the unspoken ban on war literature which, up to January 1929 had been the domain of the nationalist right. The career officers, diplomats, and officials who had published their war memoirs had dominated the genre of war literature. Their writings, which by and large proclaimed the glory, excitement, and honor inherent in fighting for one's country, were seen by those in the lower social ranks of German society as coming from a higher social caste. Because Remarque's characters reflected the life and plight of the commoner, many Germans were easily able to identify with the novel and accept it as their own story. It was refreshing 
for them to have a story about the war written by someone from their own station in life. Bernhard Kellerman, in his critique published in the Berliner Morgenpost, was among the earliest critics to pick up on this theme.

Nunmehr sind es, merkwürdigerweise, nicht mehr die Gewaltigen, die ihre Stimme erheben, es sind jetzt die Leute des Kasernenhofs ... Es sind die unbekannten Soldaten aus den Gräben und Gräbern [89].

The word unser became one of the most commonly used words in

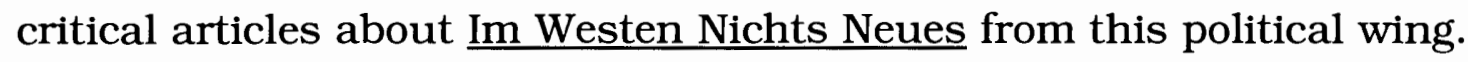
Followers of the liberal and left-liberal critics were assured by the likes of Fontana and Toller that Remarque spoke for the entire generation of front line soldiers "die im Schützengraben lagen, die verlaust und verdreckt waren, die schossen und erschossen wurden . . ." [90]. Zuckmayer extended this idea beyond just the soldiers. He suggested that all who read the novel would be drawn into the fate of Remarque's generation and as a result, would be able to identify in a personal way with the situation in which these young men found themselves [91].

Fontana went even further with this theme by implying that the experiences of the German people, and indeed the world, in the ten years following the war were a result of the war-induced restlessness of the front generation. He also alluded to Remarque in almost religious terms.

Die Frontgeneration marschiert hin und her, kreuz und quer. . . . Ihre Unruhe ist die Unruhe der Welt. Und ein Dichter wie Erich Maria Remarque erster Frühschein eines Friedens -- auch der Seele [91]. 
The president of the Preußische Dichterakademie, Walter von

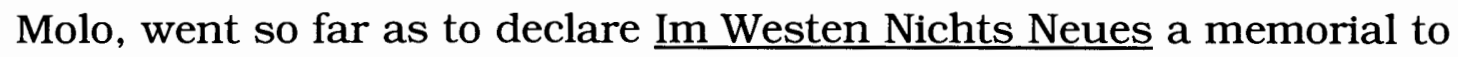
the war and to Germany's unknown soldiers [92]. Such statements from such respected critics served to draw the public at large, or at least that part of the public sympathetic to the leftist point of view, further into a personal identification with the story and the characters of the story.

Thus the novel became, at least in the minds of the leftist critics, a novel for everyone.

The third theme which characterized the critique of the liberal and left-liberal press was controversial among the members of the group. It could actually be more correctly defined not as a theme, but rather as a clash of opposing ideas centering around the question of pacifism. Many of the critics took the stance that $\underline{I m}$ Westen Nichts Neues was obviously pacifistic war literature. In Friedenswarte, for example, Dr. Fritz Sattig

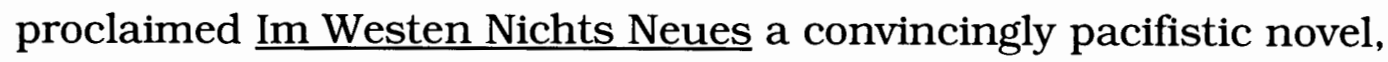

da es Schluß mache mit der gängigen literarischen "Kriegsromantik" und "dem Krieg diese romantische Larve des Heldischen von der Fratze reißt und der Jungen sagt: Kinder, das ist ja alles Schwindel; der süße und ehrenvolle Tod fürs Vaterland ist ein elendes Verrecken im Granattrichter, ein tagelanges Hängen im Stacheldraht, ein 'fröhlicher' Gastod" [93].

In furthering this theme, Dr. Karl Schröder, a critic associated with the SPD claimed that the novel was in fact a pacifistic accusation against the gruesome senselessness of the war's slaughter. This determination was made despite the fact that Remarque's preface stated 
that the novel was to be neither accusation nor confession [94]. The implication in the arguments of those calling the novel "pacifistic" was that the war had been in vain and that the atrocities of the war need never have happened [95]. It was apparently hoped by these critics that the descriptions of the battles, being as gruesome and explicit as they were, and the feelings of being hopelessly trapped and condemned to die, feelings which Remarque expressed throughout the novel, would cause his readers to realize the futility of war. With such recognition, perhaps the people would work to ensue that war would remain a thing of the past. Kellerman addressed this hope in his aforementioned critique, when he stated that "[e]s sind die Mitternachtsglocken [referring to the common soldier], die läuten: vergeßt nicht! . . Remarque . . erhebe dein furchtbares Gebrüll über die Welt!" [96].

Interestingly, it was the gruesome and explicit depiction of the battle scenes which, in part, caught the attention of those who chose to

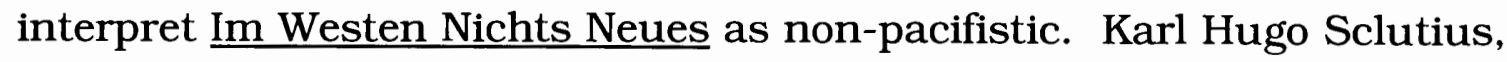
in his article "Pazifistische Kriegspropaganda" in Weltbühne took the stance that the blood-and-guts description of the war actually acted as a lure for the young boys who read the novel. "Gefahr schreckt nicht, Gefahr reizt" [97], Sclutius stated. He further suggested that after ten years of peace and having Remarque's so-called "lost generation" lording their great adventure over the younger generation, that the new generation of military-aged young men was ready for an adventure. For this and other reasons, he called Im Westen Nichts Neues "ein feines 
Sportbuch" and the war "ein feiner Sport, den das Buch preist" [98].

To further support his claim that $\underline{I m}$ Westen Nichts Neues was not a pacifistic novel, Sclutius also brought forth the assertion that the story panders to the juvenile intellect. He saw Remarque emphasizing the young soldiers' ability to overcome authority figures through acts of physical violence. He points out the apparent freedom the young soldiers have in avenging themselves against their former teacher, who they see as having been a part of the establishment which put them unprepared into the war, and against their brutal training officer, Corporal Himmelstoß, after his arrival at the front. With roles having been reversed so that Bäumer was the old hand and Himmelstoß new to the situation, Bäumer beats Himmelsto $\beta$ when he finds him cowering in a bunker during a battle. Sclutius sees such actions as the realization of juvenile urges. "Jeder Mensch hat seinen Himmelstoß" [99], and all can identify with the realization of the dream of gaining revenge against him. To be able to do so with the sanction of the military, as was apparently the case with Bäumer, makes military life even more appealing.

Walter Karsch, in his critique of Remarque's novel, declared that although the novel did portray the war as it had been, it would be "Ein

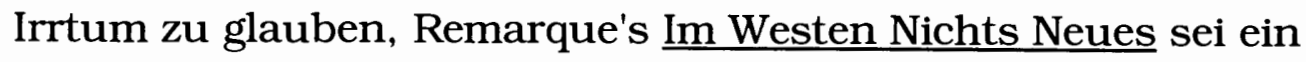
pazifistisches Buch" [100]. His basis for his disbelief in the novel's pacifism was that Remarque did not report the consequences of the war beyond his descriptions of the personal horrors suffered in the front 
trenches. Nothing was said about the consequences of the war on religious, ethical, or political levels. Karsch apparently believed that the civilian public could sympathize with the soldiers who had suffered through the terrors of the war, but were given nothing which tied in with their own experiences. This left the question "Against whom should we rebel?" open, and in so doing, also left the options for such rebellion open to whoever chose to answer the question.

The liberal and left-liberal press, then, viewed Remarque's $\underline{\text { Im }}$ Westen Nichts Neues favorably. They generally agreed that the novel was well written, depicted the war in its horrific reality, and that it reflected the situation of Germany's liberal and left-liberal population. The novel had broken the hold of the nationalist right on war literature by describing the war from the viewpoint of the unknown soldier. This viewpoint of the "little man" in the trenches rather than that of the well-known general was unique. There is little doubt, however, that a good deal of these critics' favorable opinion of the book came from the fact that the novel did not describe the German military in glowing terms, and this group was known to harbor anti-military beliefs [101]. 


\section{CHAPTER IV}

\section{CRITICISM FROM THE RIGHT}

What the political left lacked in solidarity of opinion regarding $\underline{I m}$ Westen Nichts Neues, the political right easily made up. Almost from the outset, the entire spectrum of right wing groups denounced both the novel and its author. The conservative right and the fascist right were, in fact, so closely aligned with regard to their judgment of Remarque and his novel that it would serve no purpose in this chapter to differentiate between their viewpoints. It will be more appropriate to distinguish instead between their denunciation of the novel and their attacks on Remarque's character, insofar as these distinctions can be made.

\section{RIGHTIST DENUNCIATION OF IM WESTEN NICHTS NEUES}

The view of the political right with respect to war literature was that "real" war literature "Wahrheit, Klarheit, Hoffnung, und Kraft spendet. . . . daß ohne 'positive' Sinngebung keine 'wahre' Kriegsdarstellung möglich ist" [102]. Because $\underline{\text { Im Westen Nichts }}$ Neues obviously does not present the war in a positive light, under their definition the political right proclaimed that the novel was a lie. The rightist critics did not read the novel as the fictional account of group of young soldiers' experiences on the Western Front and of the effect the 
war had on their lives, as Remarque had intended [103]. Had they read it as fiction, their denunciation of the novel as a lie would have been rendered unnecessary. Fiction is, after all, the domain of the mind of the author and need not directly reflect empirical reality if the author so chooses. These critics, however, read the novel under the assumption that it was supposed to be an attempt at a factual reporting of the war and therefore took exception to it.

Much like the Communist critics, the right wing critics alluded to the lack of dates and places in the novel in their attempts to undermine its credibility. In Die Tat, a conservative rightist newspaper, Herbert Kranz, who referred to $\underline{\operatorname{Im} \text { Westen Nichts Neues }}$ as a "Bericht", stated that Remarque "muß, weil er die Wirklichkeit nicht meistert . . . alle Situationen, was Ort und Zeit angeht, im ungewissen lassen, was jede Nachprüfung unmöglich macht" [104]. Josef Magnus Wehner, the author of Sieben vor Verdun, a war novel which was apparently well-accepted by the political right, echoed Kranz's sentiments, adding that the novel barely touched on actual history [105]. In his critique, Rudolf Georg Binding, a former cavalry officer who published his memoirs in 1925, declared that Im Westen Nichts Neues "riecht nach Unwahrheit".

Gewiß: wo der Verfasser dabei war, das is ganz gut, greifbar, recht and wahrhaft erlebt und dargestellt. [...] Aber dann kommen diese einfach aus den Fingern gesogenen Dinge, die beweisen, daß der Verfasser [nicht] dabei war [106].

Several rightist critics agreed that the tendency of the novel was so 
anti-war that it sacrificed truth in order to proclaim its insidious message. They further saw Remarque as a man who looked back on his own experiences in the war with tainted vision, and in so doing, renounced the honor of service to one's country and dispensed with literary quality as well [107]. It is interesting to note here that a great number of the conservative and fascist right critics were actually not literary critics by trade, but rather were former military personnel, many of whom had already published their own war diaries or memoirs. These critics, noting the lack of dates and places, which Remarque apparently intended to suggest that the novel was fictional, perhaps by virtue of their own past, were unable or unwilling to view the novel as anything other than an attempt at factual reporting. Because the novel portrayed a side of the war with which they could not identify, they branded the novel "eine Fälschung" [108].

Remarque's lack of heroes and heroism in his novel was also a sore point with the political right. In furthering their denunciation of the novel, the critics of the conservative and especially the National Socialist right, which taught that war was "fine, ennobling, romantic, [and] chivalrous" [109], were incensed by the fact that there was "[n]icht ein Wort von der tiefen, männlichen Erlebnisbereitschaft" [110]. They regarded Remarque as being "ganz in die Gebiete des Allzumenschlichen untergetaucht, ohne die Sterne darüber sehen zu können" [111].

In a description of their training camp days, Remarque's narrator observes that he and his comrades had expected a different role in 
military life, but found "daß wir auf das Heldentum wie Zirkuspferde vorbereitet wurden" [112]. Bäumer's description of a heavy artillery barrage followed by a French offensive which was eventually repelled describes the actions of the soldiers as those of "Automaten" [113], rather than those of men. The novel also makes frequent use of the characteristics of animals to describe the instinctual reactions of the soldiers to attacks by the enemy. These are hardly descriptions of heroics on the field of battle. Instead, they describe the actions of mindless beings defending not their fatherland, but their lives and those of their comrades against annihilation. The love for and dependence upon one's comrades, Kameradschaft, receives the credit for anything in the soldiers' actions which might otherwise be called heroics. This stand was offensive to the nationalists, who claimed that war was a heroic endeavor and that the soldiers who fought the war performed their duty with lofty thoughts of the fatherland and none for their own safety. The rightist critics deemed disavowal of heroism as the "Verblendung oder Feigheit, Schwäche und Hilflosigkeit" [1 14 ] of the author. The insinuation that there was no heroism, but only "Lebensgier" [115] and Kameradschaft, was in their view nothing less than an angry, conscious falsification of the truth [116].

Yet another point of contention of the political right with regard to

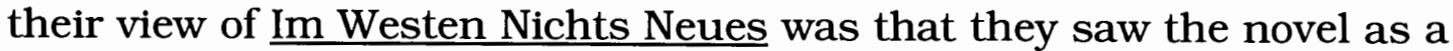
private, personal work which attempted to generalize Remarque's war experiences to all of those who fought the war. 
$[\mathrm{H}]$ ier wird nur berichtet, was ein EINZELNER sehen konnte, und einer, der in keiner Weise imstande ist, über sein unmittelbares Erleben hinauszusehen [117].

The implication here is that Remarque's war experiences cannot be generalized beyond himself, and that novels such as Remarque's should suggest neither that the war was the same everywhere nor that it was the same for everyone. The right-wing press decreed that Remarque had taken the war personally and had portrayed it in an overly personal way. One critic, Bosch, characterized Im Westen Nichts Neues as "bildfälschende Ich-literatur" and went further to state that "[m]an kann einen Krieg nicht vom Individuum her betrachten" [118]. Not surprisingly, this same judgment was not pronounced on the war diaries of Binding, the war novels of Wehner or Jünger, nor other war literature with which the rightists agreed.

Finally, the conservative and fascist right took issue with the pacifism of the novel. This pacifism threatened the very existence of right-wing beliefs. "If the war had been an absurdity, then conservatism was an absurdity; then fascism, which glorified the 'front experience' was an absurdity" [119]. Pacifism was therefore disqualified by the critics aligned with the right as being "anti-völkisch", the "Kardinalsünde wider den Volksgedanken", and as "Verrat am deutschen Volk" [120]. The concept of pacifism was apparently so abhorrent to the National Socialists, that the word Pazifismus was even raised to the level of a swear word by the National Socialist student newspaper Akademischer Beobachter, which then turned on Remarque, mocking him as a "zartes, 
pazifistisches Seelchen" [121].

Pacifism, by its nature, does not glorify war as did the right wing conservatives and fascists. Instead, it attempts to show the human side of the conflict. The anti-war novels of late Weimar Germany,

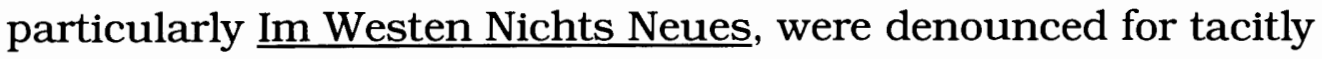
declaring the war empty and senseless, a waste of human effort and life. The rightist critics declared that the authors of such literature saw only as far as the "Tragik zerstörten Menschenlebens" and did not see beyond this to the "völkische Erneuerung" [122] which they believed to be the positive result of the soldiers' suffering and death.

\section{RIGHTIST ATTACKS ON REMARQUE}

In his interview with Axel Eggebrecht, Remarque stated that it is "[e]in altes Rezept: Kann man einer Sache nicht zuleibe, so versucht man, den Urheber zu diskreditieren" [123]. Discrediting Remarque became one of the major forms of attack used by the rightist critics of his novel, or perhaps more correctly, of the philosophy Remarque espoused in his novel. Rumors abounded as an anti-Remarque industry came to life in the wake of the success of Im Westen Nichts Neues. These rumors were likely aided by Remarque's being unwilling to become a public figure, a fact which kept him something of a mystery man [124] and therefore an easy target for slander. The National Socialists and other nationalists spread a variety of rumors, according to Wilhelm Schwarz [125]. They suggested that Remarque was, among other things, 
a French Jew, an old man who had never seen a battlefield, the effete son of millionaire parents, and a humbug whose experience on active service had been very slight.

Such rumors were, of course, substantiated with "facts", most of which were manufactured by the rumor mills of the right. To back the rumor that Remarque was a French Jew, for example, the rightists first simply needed to point out that his name appeared to be French.

Remarque had assumed his pen name when he began writing, dropping his middle name of Paul and replacing it with his mother's name, Maria, and Gallicizing his surname [126], perhaps because it appeared to him to be more poetic than the original, Remark. That he was Jewish rather than Catholic, proclaimed the rightist critics, was obvious. After all, his novel had been accepted and published by the Jewish publishing house of Ullstein [127]. To lend further credence to this particular claim, it was announced in the August 20, 1929 Munich Edition of the Völkischer Beobachter that Carl Laemmle would be making the film version of $\underline{\operatorname{Im}}$ Westen Nichts Neues. The newspaper proclaimed:

Da hat Remarque den richtigen Mann gefunden, um sein Machwerk verfilmen zu lassen. Der in Württemberg geborene und nach Amerika ausgewanderte Jude Laemmle ist seit langen Jahren geradezu Spezialist für die deutschfeindliche Propaganda des amerikanischen Filmjudentums [128].

Remarque was accorded the dishonor of guilt by association with these Jewish, and therefore, according to the National Socialists, un-German ties. 
Remarque's service at the front was among the most questioned aspects of his past used by the rightist as well as the leftist critics in attempting to undermine the validity of his portrayal of the war. Remarque, as has been stated, claimed to have been at the front long enough to have experienced just about all of what he described in his novel [129]. The critics were overjoyed when, in opposition to this claim, the President of the Reichsarchiv stated "daß in den Akten, Stammrollen und Ranglisten des Infanterie-Regiments 91 der Name Erich Paul Remark nicht zu ermitteln ist" [130]. This announcement lead to the outcry by the rightist critics that not only was the novel a lie and a fake, but so was the author.

In an article about Novemberliteraten in the October 20, 1929 Munich Edition of the Völkischer Beobachter, an anonymous author erroneously states that Remarque ("er heißt eigentlich ganz prosaisch Erich Remark, möchte aber lieber Franzose als Deutscher sein" [131]) was born in 1899 and that he therefore would have been only old enough to have been at the front a few months. Remarque was actually born in 1898, completed school and entered the army in 1916 [132]. He saw several months of fighting on the front before being wounded at Flanders in 1917, if his statements made to Eggebrecht are to be believed.

Nearly two years later, in the March 3, 1931 Munich Edition of the Völkischer Beobachter, Dr. Gottfried Rickl published an article in which he stated:

daß Remarque nur ganz kurze Zeit wirklich an der Front 
gewesen sein kann und sich dann mit einer leichten

Verwundung lange im Lazarett gehalten hat. [133]

Yet another direction of attack on Remarque brought his status as a man into question. That he was male was never questioned as far as I am able to determine, but his manliness was most certainly called into question. He was written about in the condescending tones generally accorded little children who are being made to do something they do not want to do. F.G. Jünger, for example, declared Remarque to be a weak, whining man "ohne Staatsgesinnung und ohne nationales Empfindung" [134] who had been removed against his will from his comfortable surroundings and forced into doing his duty for his country. His expression of his war experiences, because he did not rejoice in them, were deemed the "Kriegserlebnis eines Untermenschen" [134] by the right-wing propagandist Franz Schauwecker.

Another critic, Eugen Kühneman, did not stop at pronouncing Remarque's depiction of the war the shrieking of a helpless man, but

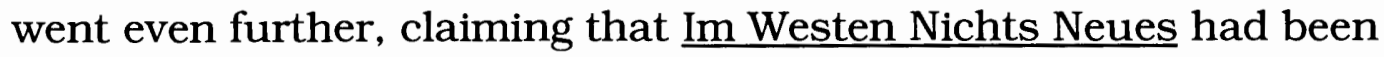
written as an act of revenge [135]. This view was held by many other critics. Hermann Pongs, a noted and well-respected Germanist, for example, called Im Westen Nichts Neues and other anti-war novels disguised acts of vengence which falsified and debased the values for which so many had died for the purpose of exalting the atrophied egos of their authors [136]. Still another right wing critic, G. Kunze, judged that Remarque's motivation in writing the novel was based in a 
"niederträchtige Rache" [137]. In a final example of this type of attack on Remarque, Juliana von Stockhausen published in her book Vom nordischen Geiste a description of a talk she had with Ingrid Undset, a Swedish Nobel Prize winner. This talk, which was reprinted in the January 13, 1931 Munich Edition of the Völkischer Beobachter, contained that statement that Frau von Stockhausen saw Remarque's book as:

das Erlebnis eines verbitterten Menschen, der sich gegen den Geist seines Volkes auflehnt und auf seine Art Rache nimmt an diesem Volke, dem er sich nicht verbunden fühlt. Es ist ein Buch ohne Soldatenehre, ohne Heroismus, ein Buch ohne Ahnen des ewigen Gesch[e]hens in der Geschichte [138].

Against whom the revenge was aimed appears to have been left for the critics' readers to decide. It was most likely enough that the rather ugly word "revenge", with all of its negative connotations, was used.

In an article that attacked both the novel and its author, Hans Zöberlein, a National Socialist author, was quick to pass judgment and, if only he had his way, sentence on Remarque. In his article, entitled "Im Westen Nichts Neues: Die Antwort eines Frontsoldaten auf das Buch Remarques", Zöberlein seems to lament the constraints imposed upon the German populace by Social Democratic societal norms. He states:

Woanders hinge ein solcher Schmierfink längst von Staats wegen an einer Laterne auf einem öffenlichen Platz der Hauptstadt zur Abschreckung. Oder er wäre von dem Frontsoldaten in seinem Element, einer Latrine, ersäuft worden [139]. 
In still another move to discredit Remarque and his novel, the critics of the conservative and National Socialist right took aim at Remarque's social status. They referred to Remarque's earlier writings, claiming that they were erotic in nature and warning the people not to be drawn in by such baseness [140]. This kind of groundwork gave credence to these critics' further claim that Im Westen Nichts Neues had come "von der Kloake her". The implication was that this "Ullsteinschmöcker" [140] was a document worthy of no more attention than Remarque's earlier works had received.

The critics aligned with the political right, then, objected almost with one voice to Remarque's novel. They took exception to any book which portrayed the war as less than a rejuvenating, honorable experience, or which reduced the worth of lost heroes' lives by suggesting that the war had been in vain. Im Westen Nichts Neues being a book which promoted the myth of Frontkameradschaft and diminished the idea of heroism, was branded a senseless portrayal which lent itself to the ethical and social deprivation of the German people [142]. 


\section{CONCLUSION}

With the exceptions of the leftists and left-liberals, it appears that the critics associated with the various political parties of late Weimar

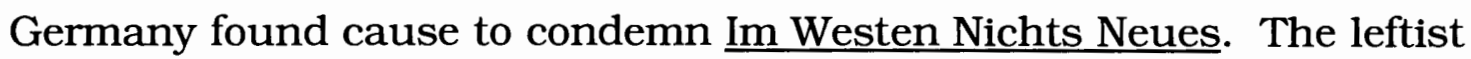
and left-liberal critics took the stand that the novel was, by and large, an accurate accounting of the war and the effects of the war on the young men who had fought and survived. Lending credence to their stand was the fact that many of the critics from this group were well-known authors of the time, and as such had a following which responded in accordance with their judgments. They proclaimed that the novel had been written about and for the average citizen, and for this reason declared it to be "their" novel [143]. Im Westen Nichts Neues was, they decided, Germany's memorial to the "unknown soldiers" of the Great War [144].

It was only with the idea of pacifism in the novel that a difference of opinion came about. The rift appeared in the apparent solidarity of opinion from the liberal and left-liberal camp when the argument was made by, most notably, Karl Hugo Sclutius that instead of a pacifistic novel, Im Westen Nichts Neues was pazifistisches Kriegspropaganda [145]. He maintained that a novel could not concurrently contain scenes of battles and convey a believable pacifistic message despite the gruesomeness of the descriptions. As proof of his 
contention, Sclutius related the following information:

Herr Studienrat Wildangel [erklärt] wie es ist, wenn er beim Unterricht Frontepisoden erzählt: "Die Augen glänzen, die Knabenkörper hocken in den Banken, wie die zum Absprung bereiten Raubtiere". . . . [und] [E]ine kluge Frau, die ihrem dreizehnjährigen Sohn den Remarque zu lesen gab und ihn fragte. Er hat geantwortet: "So etwas will man doch erleben. Und je schlimmer und gefährlicher es ist, desto interessanter ist es auch" [146].

The majority of critics of the left and left-liberal political persuasion disagreed with Sclutius and the few other critics who, for one reason or another determined Im Westen Nichts Neues to be a non-pacifistic novel. The difference of opinion remained unresolved, however, and as such a blemish on the solidarity of this group's critique of the novel.

The rest of the parties in the political arena were not as accepting of Remarque's novel. In their attacks on Remarque himself, the Communist critics were less zealous than their right-wing counterparts. They were quick, however, to point out that Remarque was representative of the sterile-minded bourgeois society, a group which they claimed had no concept of the reality of their situation or of the source of their problems. The bourgeoisie were aware that things were not right in their society, but were, according to the Communist critics, unable to determine the source of their problems. Remarque, as their representative, had resorted to tearful sentiment in an attempt to explain the difficulties of society to his social class. He pointed to the war with its inherent terror and death as the source of society's 
problems. In so doing, Remarque had simply overlooked the "fact" that the source of society's problems was actually the political-economic social structure which dominated Germany.

The critics of the nationalist and National Socialist right were less reserved in their attacks on Remarque, proclaiming him to be nearly every kind of low class creature that their rhetoric recognized. As has been stated, rumors about Remarque were spread in which he was depicted as a Jew, as a liar, as an old man with no war experience, and as the priviledged son of a millionaire. Not surprisingly, he was even branded a Marxist at one point. This occurred shortly after Wilhelm Frick, the National Socialist Minister of the Interior of the state of Thuringia, had banned Im Westen Nichts Neues from all schools in the state. In reporting the ban, a National Socialist newspaper declared "It is time to stop the infection of the schools with pacifistic Marxist propaganda"[147]. The implication that Remarque was a Marxist was obvious.

Interestingly, the Communist left and the nationalist and National Socialist right were closely aligned with each other in their denunciation of the novel Im Westen Nichts Neues. Both ends of the political spectrum chose essentially the same elements of the novel to denounce, and in a few instances were even in agreement on the reason they took exception to the novel and its author.

The general stand by the Communist critics was that $\underline{I m}$ Westen Nichts Neues was "arbeiterfeindlich" [148]. This because it did not cry 
out against the political-economic social structure which had, according to the Communist point of view, started the war in the first place. Worse yet, the novel contained no overt call for the workers to rise up against this social order.

In contrast, the critics aligned with the political right took exception to the novel mainly because it did not glorify or exalt the war experience as they did. There were no heros in Remarque's novel. There were only men who were rendered essentially mindless by the military machine and who, as a result, fought for preservation of self at an instinctual level. There was no fighting for love of country at a more ethereal level.

Despite the apparent differences in the political perspectives of the Communists and the entire political right in denouncing $\underline{\operatorname{Im} \text { Westen }}$ Nichts Neues, the actual reason for lashing out at the novel was essentially identical. If Remarque's philosophy as depicted in his novel were to be accepted by the German people, it would call into question the ideals of these parties and thereby call their reason for existence to account.

As far as the Communists were concerned, if Remarque's tacit suggestion that the war was fated to happen were to be believed, then the idea of being in the hands of fate would generalize to other areas of life. This would eventually lead to the conclusion that a person's station in life is also determined by the whims of fate. If this were the case, there would be nothing left to do except to throw one's hands in the air 
and passively accept the life one had been given. There could, under such circumstances, be no revolution or uprising. Who, after all, could stand up to or fight against something as nebulous as fate?

The political right, and especially the National Socialist right, on the other hand, were threatened by the idea that war was perhaps a vain, senseless gesture. In particular the National Socialists needed to believe, and needed the people to believe, that war was a grand thing which clarified and renewed nations and created heroes. They further contended that there was a certain level of romance associated with war. If Remarque were to be believed, the romance did not exist. Instead war was simply a hellish existence which was "eine Todesursache wie Krebs und Tuberkulose, wie Grippe und Ruhr" [149]. If there were, in fact, no heroes fighting for their homeland, but only men who fought and killed to avoid being killed themselves, then their nationalist ideology would be rendered ludicrous.

Remarque's view of Kameradschaft also came under fire by critics at both ends of the political spectrum. Kameradschaft, according to Remarque, was the one good thing to come out of the war experience. The soldiers' love and dependence upon each other which resulted from working together under such adverse conditions as those presented by the war created friendships which, without the existence of the war, would never have occurred. Kameradschaft, claimed Remarque, was the reason behind many of the acts which those not involved directly in the war might have called heroism. 
The Communist critics reaction was again one which defended their reason for existence. Remarque described Kameradschaft as a social leveler among those serving at the front. The Communists were unable to accept this leveling because it destroyed the very thing against which they hoped to arise and fight. If the officers and the enlisted and conscripted soldiers became equal, if the educated became equal with the uneducated, then who would be left to oppose? The erasure of class opposites through Kameradschaft could not be allowed to be believed. If it were, it would show that the boundaries between social classes were false boundaries.

The critics from the rightist camps tied their arguments against Kameradschaft again to the idea of heroism. The concept of Kameradschaft eclipsed the ideal of a soldier risking his life for the sake of country with the "reality" of that soldier's risking his life either because he has no choice or because his comrade is in need of his help. If this "reality" were accepted by the people, it would mean that many national figures would suddenly lose their credibility and status as a hero. Taken even further, it would mean that no one could be driven to fight a war for his country on the basis of the lofty ideal of heroism.

When it came to the pacifism of the novel, no critics in any of the political camps, with the exception of the liberal and left-liberal critics already mentioned, seemed to dispute that the novel was pacifistic in nature. Rather, they denounced the novel's pacifism almost with a single voice. The Communists, the rightists, and the National Socialists 
all declared $\underline{I m}$ Westen Nichts Neues to be a lie. To all of these groups, the words "pacifism" and "lie" took on essentially the same definition. Remarque's novel was read not as a novel, but as an attempt at an accurate report of life on the Western Front, despite Remarque's statement to Axel Eggebrecht that it was not intended to be such.

[M]ein Buch . . . beschränkt sich ja bewußt auf einen ganz kleinen Ausschnitt des Krieges. . . . [Es ist] unvollständig, weil es nur von der Erlebnissen einiger junger Schülersoldaten und ihrer Freunde handelt . . . weil es nur von einer Waffengattung ... einem Kriegsschauplatz handelt . . . vor allem . . . weil es nur auf wenige Monate begrenzten Zeitraum aus dem letzten beiden Kriegsjahren umfaßt [150].

Taken as a factual account, then, even Remarque would have found it necessary to denounce the novel as a falsification of the history of the entire war.

The supposed error made by these political groups in reading the novel as a report rather than as fiction may well have been no error. It is not unlikely that these critics purposely chose to undermine the portrayals in the novel as a report rather than as a fictional novel in order to assure that no one would choose to accept it as a report. The initial positive response $\underline{I m}$ Westen Nichts Neues received, and the continual proclamation of the liberal and left-liberal critics, as well as many of the former front soldiers, that the novel portrayed the war realistically was a threat. The political groups whose existence was threatened by this had virtually no choice but to react as they did. Ironically, if this is the case their reaction to the "attack" of Remarque's 
philosophy on their philosophies runs parallel to Bäumer's description of the reactions of the soldiers when under attack. It is the instinctual reaction of self-preservation.

More modern critics, particularly Modris Eksteins and A. F. Bance, have brought forward an interesting amendment to the discussion of $\underline{I m}$ Westen Nichts Neues. It appears that the National Socialist critics may have been fighting on the wrong side of the argument. In the novel, Bäumer refers to the propaganda which had been found on the French prisoners of war.

Drüben wird aber mehr gelogen als bei uns . . . denkt mal an die Flugblätter der Gefangenen, in denen stand, daß wir belgische Kinder fräßen [151].

That the Germans were regarded as an untrustworthy and dangerous people at the end of the war is understandable in light of the kinds of propaganda which had been circulated about them. To further support this opinion was the fact that the Germans had been assigned the guilt for the war under Article 231 of the Versailles Treaty.

According to Eksteins, however, "Remarque's novel did a great deal to undermine the view that Germans were 'peculiar' and not to be trusted" [152]. Bance adds that "Remarque may . . . have been influential in lulling his foreign readership into a false sense of security" [153]. If this is actually the case, then the National Socialists may have erred in attacking Remarque's novel. They may, in fact, have met with earlier and greater success in their political endeavors had they, at least in part, supported the views espoused by Remarque in $\underline{\text { Im Westen Nichts }}$ 
61

Neues. 


\section{ENDNOTES}

\section{Introduction}

1. The Long Generation: Germany from Empire to Ruin 1913 - 1945. ed. Henry Cord Meyer. New York: Walker, 1973. 221

2. Engelmann, Bernt. Einig Gegen Recht und Freiheit: Deutsches Anti-Geschichtsbuch. 2. Teil. München: Bertelsmann, 1975. 295

3. Eksteins, Modris. The Limits of Reason: The German Democratic Press and the Collapse of Weimar Germany. Oxford U P, 1975. 216

4. Bance, A. F.. "'Im Westen Nichts Neues': A Bestseller in Context," Modern Language Review 72 (1977): 359

5. Graf Kessler, Harry. Tagebücher 1918 - 1937. Hg. von Wolfgang Pfeiffer-Belli. 4. Auflage. Frankfurt/M.: Insel, 1961. 592

6. Pinthus, Kurt. "'Männliche Literatur,' In: Das Tagebuch 10. (1. Juni 1929) H. 1, S. 903 - 911." Weimarer Republik: Manifeste und Dokumente zur Deutschen Literatur 1918 1933. Hg. von Anton Kaes. Stuttgart: Metzler, 1983. 328

7. Bance. 361

8. Laqueur, Walter. Weimar: A Cultural History 1918 - 1933. London: Weidenfeld, 1974. 135

9. Hermand, Jost, and Frank Trommler. Die Kultur der Weimarer Republik. München: Nymphenburger, 1978. 256

10. Eggebrecht, Axel. "'Gespräch mit Remarque,' In: Die Literarische Welt 5. (14. Juni 1929) Nr. 24, S. 1-2." Weimarer Republik: Manifeste und Dokumente zur Deutschen Literatur 1918 1933. Hg. von Anton Kaes. Stuttgart: Metzler, 1983. 517 
11. Eksteins, Modris. "All Quiet on the Western Front and the Fate of a War," Journal of Contemporary History 15 (1980) 352 353

12. Sontheimer, Kurt. Antidemokratisches Denken in der Weimarer Republik. München: Nymphenburger, 1964. 120

13. Sontheimer. 119

\section{Chapter I}

14. Remarque, Erich Maria. Preface. All Quiet on the Western Front. trans. A. W. Wheen. New York: Fawcett, 1975 N. pag.

15. Remarque, Erich Maria. Im Westen Nichts Neues. 40.Auflage. Frankfurt/M.: Ullstein, 1991. 22-23

16. Remarque. Westen. 21-22

17. Remarque. Westen. 66

18. Remarque. Westen. 184

19. Remarque. Westen. 70

20. Remarque. Westen. 84

21. Remarque. Westen. 102

22. Bonadeo, Alfredo. Death and Degradation in the Literature of the Great War. U P Kentucky, 1983. 43

23. Gollbach, Michael. Die Wiederkehr des Weltkrieges in der

Literatur: Zu den Frontromanen der späten Zwanziger Jahre. Kronberg/Ts.: Scriptor, 1978. 46

24. Remarque. Westen. 190

25. Remarque. Westen. 86

26. Remarque. Westen. 158

27. Remarque. Westen. 138

28. Remarque. Westen. 102 
29. Remarque. Westen. 125

30. Remarque. Westen. 21

31. Remarque. Westen. 20

32. Remarque. Westen. 88

33. Remarque. Westen. 116

34. Remarque. Westen. 124

35. Remarque. Quiet. 236

36. Gollbach. 47

37. Remarque. Westen. 138

38. Remarque. Westen. $66-67$

39. Remarque. Westen. 196

40. Remarque. Westen. 203

41. Remarque. Westen. 203

42. Remarque. Westen. 204

43. Gollbach. 54

44. Remarque. Westen. 25

45. Remarque. Westen. 72

46. Gollbach. 54

47. Remarque. Quiet 24

48. Remarque. Westen. 189

49. Remarque. Quiet. Preface

50. Remarque. Westen. 160

51. Eksteins. Fate. 350

52. Remarque. Quiet. 93 
Chapter II

53. Gollbach. 43

54. Müller, Hans-Harald. Der Krieg und die Schriftsteller: Der Kriegsroman der Weimarer Republik. Stuttgart: Metzler, 1986. 71

55. Eksteins. Fate. 348

56. Bance. 360

57. Graf Kessler. 592

58. Eggebrecht. 514

59. Eggebrecht. $514-515$

60. Eggebrecht. 515

61. Bance. 366

62. Eksteins. Fate. 349

63. Bance. 364

64. Eksteins. Fate. 351

65. Eggebrecht. $514-515$

66. Müller. 41

\section{Chapter III}

67. Müller. $73-74$

68. Gollbach. 309

69. Gollbach. 309

70. Eksteins. Fate. 355

71. Gollbach. 311

72. Gollbach. 310 
73. Neukranz, Klaus. "Remarque: 'Im Westen Nichts Neues'," $\underline{\text { Rote }}$ Fahne Berlin 3 März, 1929: N.pag.

74. Gollbach. 310

75. Gollbach. 311

76. Müller. 74

77. Müller. 93

78. Gollbach. 312

79. Gollbach. 310

80. Bance. 365

81. Gollbach. 313

82. Müller. 92

83. Biographisches Lexikon zur Weimarer Republik. Hg. von Wolfgang Benz und Hermann Graml. München: Beck, 1988. 378

84. Müller. 75

85. Eksteins. Fate. 354

86. Müller. 76

87. Gollbach. 314

88. Müller. 73

89. Müller. 75

90. Müller. 76

91. Müller. 77

92. Müller. $75-76$

93. Müller. 81

94. Müller. 72

95. Eksteins. Fate. 355 
96. Müller. 75

97. Sclutius, Karl Hugo. "Pazifistische Kriegspropaganda," Weltbühne April 2, 1929: 522

98. Sclutius. 522

99. Sclutius. 520

100. Müller. 73

101. Müller. 76

\section{Chapter IV}

102. Gollbach. 300

103. Eksteins. Fate. 349

104. Müller. 67

105. Gollbach. 297

106. Müller. 68

107. Gollbach. 297

108. Müller. 70

109. Meyer. 243

110. Gollbach. 296

111. Gollbach. 299

112. Remarque. Westen. 22

113. Remarque. Westen. 86

114. Gollbach. 295

115. Remarque. Westen. 85

116. Gollbach. 296 
117. Gollbach. 294

118. Gollbach. 295

119. Eksteins. Fate. 355

120. Gollbach. 298

121. Gollbach. 299

122. Gollbach 299

123. Eggebrecht. 514

124. Bance. 359

125. Schwarz, Wilhelm J. War and the Mind of Germany. I. . European Univ Papers. Bern: Lang, 1975. 140

126. Eksteins. Fate. 347

127. Pachter, Henry. Weimar Etudes. New York: Columbia U P, 1982. 123

128. "Laemmle verfilmt Remarque," Völkischer Beobachter München 20 August, 1929: N. pag.

129. Müller. 41

130. Müller. 71

131. "Novemberliterraten," Völkischer Beobachter München 20 Okt, 1929: N. pag.

132. Deutsche Dichter und Schriftsteller unserer Zeit:

Einzeldarstellung zur Schönen Literatur in deutscher Sprache. 10. erweiterte Auflage. Stuttgart: Kröner, 1969. 556

133. Rickl, Gottfried. "Im Westen Nichts Neues und sein wahrer Sinn," Völkischer Beobachter München 3März, 1931: N. pag.

134. Sontheimer. 119

135. Gollbach 296

136. Schwarz. 143 
137. Gollbach. 301

138. Von Stockhausen, Julianna, "Das Urteil einer deutschen Frau über Remarques Buch: Ein Buch ohne Soldatenehre, ohne Heroismus," Völkischer Beobachter München 13 Jan, 1931 N. pag.

139. Zöberlein, Hans, "Im Westen Nichts Neues: Die Antwort eines Frontsoldaten auf das Buch Remarques," Völkischer Beobachter München (Beilage) Der Frontsoldat 14 Aug, 1929: 1

140. Gollbach. 301

141. Gollbach. 301

142. Gollbach. 300

$\underline{\text { Conclusion }}$

143. Müller. 76

144. Müller. $75-76$

145. Sclutius. 517

146. Sclutius, Karl Hugo. "Nochmals: Pazifistische Kriegspropaganda," Weltbühne. May 28, 1929827

147. Eksteins. Fate. 357

148. Gollbach. 309

149. Remarque. Westen. 189

150. Eggebrecht. $514-515$

151. Remarque. Westen. 146

152. Eksteins. Fate. 361

153. Bance. 371 


\section{REFERENCES}

Bance, A. F. "'Im Westen Nichts Neues': A Bestseller in Context." Modern Language Review 72 (1977): 359-373.

Benz, Wolfgang und Hermann Graml, Hg. Biographisches Lexikon zur Weimarer Republik. München: Beck, 1988.

Bonadeo, Alfredo. Death and Degradation in the Literature of the Great War. U P Kentucky, 1983.

Denkler, Horst, und Karl Prümm, Hg. Die Deutsche Literatur im Dritten Reich: Themen - Traditionen- Wirkungen. Stuttgart: Reclam, 1976.

Deutsche Dichter und Schriftsteller unserer Zeit: Einseldarstellung zur Schönen Literatur in deutscher Sprache. 10. erweiterte Auflage. Stuttgart: Kröner, 1969.

Eksteins, Modris. The Limits of Reason: The German Democratic Press and the Collapse of Weimar Germany. Oxford: Oxford U P, 1975.

Eksteins, Modris. "All Quiet on the Western Front and the Fate of a War." Journal of Contemporary History 15 (1980): 345 366.

Eksteins, Modris. "War, Memory, and Politics: The Fate of the Film 'All Quiet on the Western Front'." Central European History 13 (1980): $60-82$.

Engelmann, Bernt. Einig Gegen Recht und Freiheit: Deutsches Anti-Geschichtsbuch. 2. Teil. München: Bertelsmann, 1975.

Gay, Peter. Weimar Culture: The Outsider as Insider . New York: Harper, 1968.

Gollbach, Michael. Die Wiederkehr des Weltkrieges in der Literatur: Zu den Frontromanen der späten Zwanziger Jahre. Kronberg/Ts.: Scriptor, 1978. 
Graf Kessler, Harry. Tagebücher 1918 - 1937. Hg. von Wolfgang Pfeiffer-Belli. 4. Auflage. Frankfurt/M.: Insel, 1961.

Hermand, Jost, und Frank Trommler. Die Kultur der Weimarer Republik. München: Nymphenburger, 1978.

Kaes, Anton, Hg. Weimarer Republik: Manifeste und Dokumente zur Deutschen Literatur 1918 - 1933. Stuttgart: Metzler, 1983.

"Laemmle verfilmt Remarque." Völkischer Beobachter 20 Aug. 1929, München: N. pag.

Laqueur, Walter. Weimar: A Cultural History 1918 - 1933. London: Weidenfeld, 1974.

Meyer, Henry Cord, ed. The Long Generation: Germany from Empire to Ruin 1913 - 1945. New York: Walker, 1973.

Movie, Charles. "Der Dichter und der Führer." Weltbühne 9 April 1929: 576

Müller, Hans-Harald. Der Krieg und die Schriftsteller: Der Kriesroman der Weimarer Republik. Stuttgart: Metzler, 1986.

Neukranz, Klaus. "Remarque: 'Im Westen Nichts Neues'." Rote Fahne 3 März, 1929, Berlin: N. pag.

"Novemberliteraten." Völkischer Beobachter 20 Okt. 1929, München: N. pag.

Pachter, Henry. Weimar Etudes. New York: Columbia U P, 1982.

Remarque, Erich Maria. All Quiet on the Western Front. Trans. A. W. Wheen. New York: Fawcett, 1975.

Remarque, Erich Maria. Im Westen Nichts Neues. 40. Auflage. Frankfurt/M.: Ullstein, 1991.

Rickl, Gottfried. "Im Westen Nichts Neues und sein wahrer Sinn." Völkischer Beobachter 3 März 1931, München, N. pag.

Schwarz, Wilhelm J. War and the Mind of Germany. I. . European Univ. Papers. Bern: Lang, 1975.

Sclutius, Karl Hugo. "Pazifistische Kriegspropaganda." Weltbühne 2 Apr. 1929: 517 - 522. 
---. Nochmals: "Pazifistische Kriegspropaganda." Weltbühne 28 Mai, 1929.

Sontheimer, Kurt. Antidemokratische Denken in der Weimarer Republik. München: Nymphenburger, 1964

Von Stockhausen, Julianna. "Das Urteil einer deutschen Frau über Remarques Buch: Ein Buch ohne Soldatenehre, ohne Heroismus." Völkischer Beobachter 13 Jan. 1937, München, N. pag.

"Was war im Krieg?" Frankfurter Zeitung 29 Jan., 1929. N. pag. Zöberlein, Hans. "Im Westen Nichts Neues: Die Antwort eines Frontsoldaten aut das Buch Remqarques" (Beilage) Der Frontsoldat 14 Aug. 1929 